\title{
Corrigendum
}

\section{Consociational democracy at stake: Four approaches to explain Lebanon past and present}

\author{
Danilo Di Mauro
}

Acta Politica (2013) 48, 117. doi:10.1057/ap.2012.38

Correction to: Acta Politica (2008) 43, 453-471. doi:10.1057/ap.2008.15

Please note that part of this article contains significant similarities in phrasing and structure to Joseph G Jabbra and Nancy W Jabbra (2001). 'Consociational Democracy in Lebanon: A Flawed System of Governance', Perspectives on Global Development and Technology 17(2): 71-89, without proper acknowledgment of the original authors or source. 